\title{
73. CAN OPAL-A/OPAL-CT BSR BE AN INDICATOR OF THE THERMAL STRUCTURE OF THE YAMATO BASIN, JAPAN SEA? ${ }^{1}$
}

\author{
S. Kuramoto, ${ }^{2}$ K. Tamaki, ${ }^{2}$ M. G. Langseth, ${ }^{3}$ \\ D. C. Nobes,${ }^{4}$ H. Tokuyama,${ }^{2}$ K. A. Pisciotto, ${ }^{5}$ and A. Taira ${ }^{2}$
}

\begin{abstract}
One of the important results of the Japan Sea drilling by ODP is the detection of an opal-A/opal-CT transformation at all the drill sites. The transformation boundary is well recognized in physical property and downhole measurements as well as in lithologic descriptions. Because the boundary shows a marked change of density, the boundary appears in seismic reflection profiles as a BSR. The transformation of opal-A to opal-CT is closely correlated with temperature and age of host rock in the Japan Sea. We estimate and evaluate Japan Sea heat flow by using the opal-A/opal-CT bottom simulating reflector (BSR) observed in seismic reflection profiles. Then we estimated the age of host rock from available seismic profiles based on the assumption of constant sedimentation rate. Therefore, the temperatures at opal-A/opal-CT boundary were estimated from seismic profiles. The temperature data were converted to surface heat flow data by using the thermal conductivity data obtained by shipboard physical property measurements. The estimated BSR heat flow showed significant agreement with individual probe heat flow data. We confirmed the validity of BSR heat flow on a multichannel seismic profile. This method can provide large areal estimates of the surface heat flow. The opal-A/opal-CT BSR can contribute to defining the thermal structure of the Yamato Basin, Japan Sea.
\end{abstract}

\section{INTRODUCTION}

Ocean Drilling Program (ODP) scientific drilling was carried out in the Japan Sea in 1989. Legs 127 and 128 drill sites are shown in Figure 1. One of the significant results of the Japan Sea drilling was the identification of a silica diagenetic phase boundary in the sedimentary sections at all drill sites (Tamaki, Pisciotto, Allan, et al., 1990; Ingle, Suyehiro, von Breymann, et al., 1990). The opal-A (amorphous silica) to opal-CT (cristobalite) transition was clearly characterized by the physical property measurements (Nobes et al., this volume). The boundary also correlates with strong reflectors in seismic reflection profiles (Tamaki, Pisciotto, Allan, et al., 1990).

Bottom simulating reflectors (BSRs) are observed in some seismic reflection profiles as a prominent reflector in the sediments. Two kinds of BSRs are now well known; one is the reflector from the bottom of gas hydrate layers and the other is the BSR at the diagenetic silica phase change boundary from opal-A to opal-CT in siliceous sediments (opal-A/opal-CT BSR). Gas hydrate BSRs are commonly observed at continental margins (e.g., Bryan, 1974; Shipley et al., 1979; Aoki et al., 1982). In contrast, BSRs resulting from the opal-A/opal-CT phase change are rare. Hein et al. (1978) first demonstrated the existence of an opal-A/opal-CT transition BSR on seismic reflection profiles in the Bering Sea. Grechin et al. (1981) and Hubbard et al. (1985) also mentioned the silica phase change off Baja California and off central California, respectively. There have been no observations since then except for that recorded in the Japan Sea (Tamaki, Pisciotto, Allan, et al., 1990; Ingle, Suyehiro, von Breymann, et al., 1990). ODP drilling thus provided the first opportunity to study in detail the significance

\footnotetext{
'Tamaki, K., Suyehiro, K., Allan, J., McWilliams, M., et al., 1992. Proc. ODP, Sci. Results, 127/128, Pt. 2: College Station, TX (Ocean Drilling Program).

${ }^{2}$ Ocean Research Institute, University of Tokyo, 1-15-1, Minamidai, Nakano-ku, Tokyo 164, Japan.

${ }^{3}$ Lamont-Doherty Geological Observatory, Columbia University, Palisades, NY 10964, U.S.A

${ }^{4}$ Department of Earth Sciences and Department of Physics, University of Waterloo, Waterloo, Ontario N2L 3G1, Canada. Present address: Department of Geology, University of Canterbury, Private Bag, Christchurch, New Zealand.

${ }^{5}$ BP Exploration Company Ltd., Britannic House, Moore Lane, London EC2Y 9BU, U.K.
}

of an opal-A/opal-CT BSR and its relation to basin evolution, and the thermal structure of the basin.

The transformation of biogenic silica from opal-A to opal-CT is known to occur with increasing burial depth (e.g., Jones and Segnit, 1971; Iijima and Tada, 1981). The primary controlling factors of this phase change include temperature, time, surface area of test, porewater chemistry, lithology, and permeability (Lewin, 1961; White and Corwin, 1961; Siever, 1962; Mizutani, 1966, 1970; Hurd, 1972; Lancelot, 1973; Wollast, 1974; Murata and Nakata, 1974; Kastner et al., 1977). Among these factors, temperature and time are the most important. Phase transition of opal-A to opal-CT is a dehydration reaction that creates an increase in the silica density and can increase the acoustic impedance in silica-rich sediments. Thus in seismic profiles, the opal-A/opal-CT diagenetic boundary can produce a strong bottom simulating reflection. In this paper we attempt to estimate and evaluate the heat flow values based on the observed opal-A/opal-CT BSR.

\section{OPAL-A/OPAL-CT TRANSITION IN THE JAPAN SEA}

The sedimentary sections in the basins of the Japan Sea have a rather uniform lithology, suggesting that they were deposited under uniform geological conditions. The upper part of the sedimentary sequence is composed of diatomaceous sediments in which the opal-A/opal-CT diagenetic change is observed. The boundary is evident in X-ray-diffraction, physical property, and downhole measurements (Tamaki, Pisciotto, Allan, et al., 1990). The boundary is particularly defined in the physical property data (Nobes et al., this volume). The density and porosity profiles show a sharp, large offset at each site except Site 796 on the Okushiri Ridge, where complex tectonic disturbance seems to have produced a different pattern of physical property profile.

The opal-A/opal-CT boundary temperatures for all Leg 127/128 sites, estimated by extrapolation of downhole temperature measurements (Tamaki, Pisciotto, Allan, et al., 1990, Langseth and Tamaki, this volume), are listed in Table 1. The estimated temperatures at the opal-A/opal-CT boundaries in the Yamato Basin are $36.5^{\circ} \mathrm{C}$ at Site 794 (293-297 mbsf) and $36.0^{\circ} \mathrm{C}$ at Site 797 (299 mbsf). These temperatures show extraordinary agreement despite the large distance between the sites. The age of the boundary at each site is also shown 


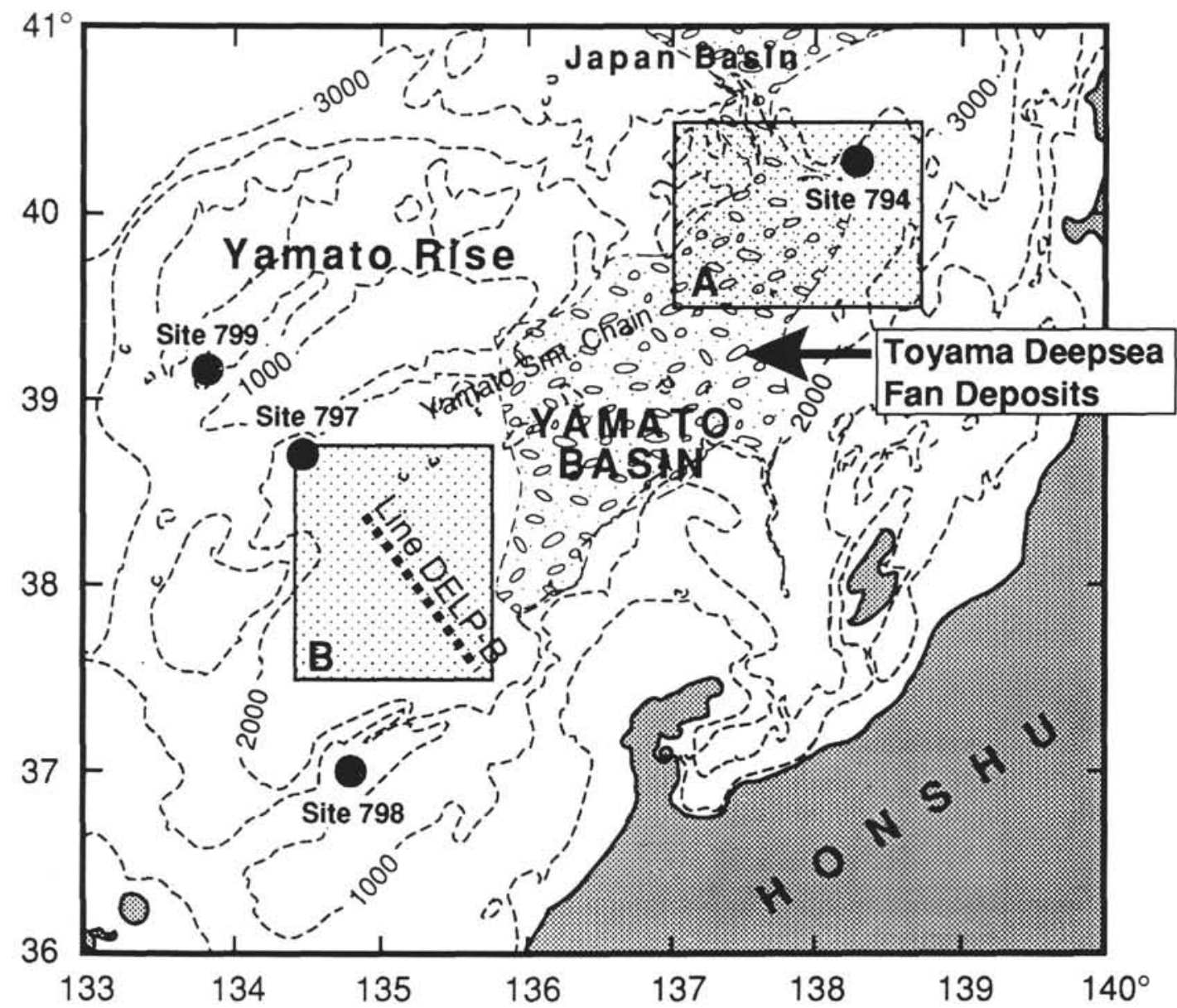

Figure 1. Location map of ODP Legs 127 and 128 drill sites in and around the Yamato Basin. Dashed line locates multichannel seismic reflection profile (DELP-B) shown in Figures 4 and 9. Shaded areas (A and B) correspond to areas in Figure 10. The distribution of Toyama Deepsea Fan deposits is also shown.

in Table 1. The errors in temperature measurement and age estimation are quite small. Using these data, we have constructed the temperature-age relationship of the Japan Sea opal-A/opal-CT phase transition shown in Figure 2. The opal-A to opal-CT transition temperatures are higher as the host rock becomes younger. Therefor, the opal-A/opal-CT phase change boundary cannot be regarded as an isothermal boundary. We use the transformation temperature/age relationship to estimate temperature gradients throughout the Yamato Basin.

\section{OPAL-A/OPAL-CT TRANSITION BOUNDARY IN SEISMIC REFLECTION PROFILES}

The opal-A/opal-CT transition is accompanied by a significant density change ( $20 \%$ increase) that results from the dissolution of diatom tests at the diagenetic phase boundary and reprecipitation as disseminated cristobalite (Tamaki, Pisciotto, Allan, et al., 1990; Nobes et al., this volume). The density changes abruptly at the phase boundary of most sites, as shown in the physical property and downhole measurements (Tamaki, Pisciotto, Allan, et al., 1990). The boundary is often observed in seismic reflection profiles due to the sharp change in acoustic impedance at the boundary.

A BSR is observed throughout the Japan Sea. To verify that this BSR correlates with this opal-A/opal-CT diagenetic boundary, we calculated synthetic seismograms for Sites 794 and 797 based on the physical property and downhole measurements. Acoustic impedance is the product of two variables, velocity and density. The strength of the seismic reflection is directly related to the contrast in acoustic impedance across a boundary. We used density values obtained by discrete shipboard measurements of core samples. The $P$-wave logger, Hamilton frame, and downhole logging velocities were combined into a single velocity profile that was used for both sites. The density and velocity data were converted to two-way traveltime, sorted at $10-$ to 20-ms intervals, and convoluted with a modified Ricker-type wavelet $(20 \mathrm{~Hz})$. The resulting acoustic impedance, reflection coefficient, and synthetic seismogram are shown in Figure 3.

Both synthetic seismograms show that the opal-A/opal-CT boundaries produce strong reflectors (Fig. 3). The depths of opal-A/opal-CT reflectors in the synthetic seismograms coincide with the depths of opal-A/opal-CT boundary from drilling results at Sites 794 and 797. The

Table 1. Temperatures $\left({ }^{\circ} \mathrm{C}\right)$ at the opal-A/opal-CT transformation boundary and ages (Ma) of the host rocks. The temperatures are estimated from the combination of downhole temperature measurements and shipboard thermal conductivity measurements (Tamaki, Pisciotto, Allan, et al., 1990; Ingle, Suyehiro, von Breymann, et al., 1990; Langseth and Tamaki, this volume).

\begin{tabular}{lrrrrrr}
\hline Site & 794 & 795 & 796 & 797 & 798 & 799 \\
Temp. & 36.5 & 44.0 & 42.5 & 36.0 & 51.0 & 46.0 \\
Age & 8.0 & 5.2 & 6.3 & 8.0 & 3.8 & 6.4 \\
\hline
\end{tabular}




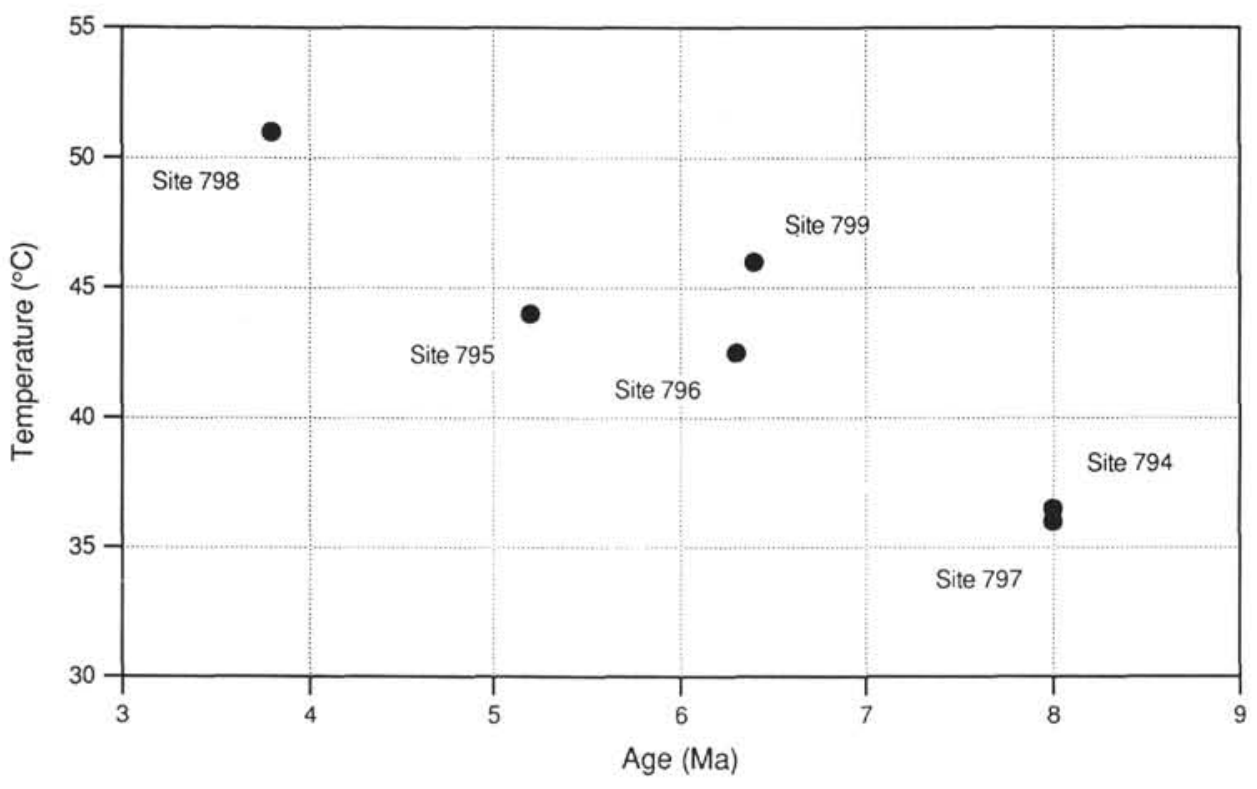

Figure 2. Relationship between host rock age and temperature at the opal-A/opal-CT transition boundary based on drilling results.

strong reflection results from an abrupt change of density rather than the gradual change of velocity. The velocity of the Yamato Basin sediments increases almost linearly with depth and shows no significant jumps in value that compare to the density variation in the Yamato Basin (Tamaki, Pisciotto, Allan, et al., 1990). Consequently, the reflection coefficient is primarily controlled by the sharp change of density across the opal-A/opal-CT boundary. Thus, the opal-A/opalCT transition in the Yamato Basin sediments produces a pronounced reflector with no significant reflectors in the time intervals above or immediately below the opal-A/opal-CT boundary; the opal-A/opal$\mathrm{CT}$ reflector usually stands out as a clear seismic marker (Fig. 4). The opal-A/opal-CT transition creates BSRs that have normal polarity throughout most of the Japan Sea. This distinguishes them from gas hydrate BSRs, which have reverse polarity.

An example of the opal-A/opal-CT BSR in the Yamato Basin (southeastern part of Line DELP-B, Fig. 1) is shown in Figure 4. The BSR in the Yamato Basin occurs at about $4.5 \mathrm{~s}$ two-way traveltime (TWT) and is characterized by a remarkably high amplitude compared with the sedimentary reflectors immediately above and below it. Thus, it is easily recognized even in the midst of other subparallel reflectors, and it is possible to trace the BSR in most areas of the Yamato Basin. We use the BSR in the Yamato Basin as an example to evaluate the feasibility of using it as an indicator of basin thermal structure.

\section{ESTIMATION OF HEAT FLOW FROM THE YAMATO BASIN BSR}

The Yamato Basin is one of the most intensively surveyed backarc basins in the world (Fig. 1). It is located south of the Yamato Rise and trends northeast to southwest. The relatively smooth seafloor of the Yamato Basin is disturbed by the Yamato Seamount Chain, which is aligned with the central axis of the basin. The water depth of the Yamato Basin ranges from 2700 to $3000 \mathrm{~m}$, which is approximately 500 to $1000 \mathrm{~m}$ shallower than that of the Japan Basin, north of the Yamato Rise. During the past three decades, numerous heat flow measurements have been made in the Yamato Basin by Yasui et al. (1966), Yoshii (1972), and Yamano et al. (1987) using 1.5- to 4.5-m probes with multiple temperature sensors (Fig. 5).

An attempt is made here to estimate the heat flow values of the whole Yamato Basin using the temperature-age relationship of opal-A/opal-CT transition established by the results of ODP Japan Sea Legs 127 and 128 (Fig. 6) and available seismic reflection profiles. Figure 6 shows temperature and age data for ODP Sites 794 to 799 and data from Deep Sea Drilling Project (DSDP) and test wells in northern Japan (Tada, 1991). The solid line shows the best fit curve for the ODP data. The dashed line shows the best fit curve for all the data (Fig. 6). The curves intersect at about $8 \mathrm{Ma}$. Because the temperature difference is very small for a host rock age of $8 \mathrm{Ma}$, either curve (Fig. 6) can be used to estimate the temperature of the Yamato Basin. We prefer using the best fit curve for ODP data to estimate the transition temperature from opal-A to opal-CT because there is less scatter in the ODP data.

The host rock age of the opal-A/opal-CT BSR can be determined using the depth of BSR and the sedimentation rate above the BSR. The depth of BSR is calculated using the velocity data of the physical property measurements and logging data, which is the same used for the synthetic seismogram calculation. The sedimentation rates are nearly constant at approximately $37 \mathrm{~m} / \mathrm{m}$.y. at Sites 794 and 797 based on the drilling results (Tada, this volume). Seismic data also show that the stratigraphy is relatively uniform except for the Toyama Deepsea Fan deposits, which are distributed in the middle to northwestern area of the Yamato Basin (Fig. 1, Kuramoto, unpubl. data). Thus, we assume that the sedimentation rate obtained by drilling results can be used to estimate age of the opal-A/opal-CT BSR basinwide. The thermal conductivity of the sediments is almost constant $(0.85 \mathrm{~W} / \mathrm{m} \cdot \mathrm{K})$ above the opal-A/opal-CT transition boundary (Tamaki, Pisciotto, Allan, et al., 1990). Therefore, heat flow values can be estimated by identification of the opal-A/opal-CT BSRs in seismic reflection profiles. Figure 7 shows the relationship between the two-way traveltime from seafloor to the opal-A/opal-CT BSR, the opal-A/opal-CT transition boundary temperature, and the surface heat flow value.

\section{VALIDITY OF HEAT FLOW ESTIMATION FROM OPAL-A/OPAL-CT BSR}

\section{Effect of Sedimentation Rate}

Estimation of surface heat flow strongly depends on identification of the opal-A/opal-CT BSR and estimation of the sedimentation rate. We calculated the surface heat flow values for various sedimentation rates (Fig. 8). Figure $8 \mathrm{~A}$ shows the relationship between BSR depth and expected heat flow values for sedimentation rates that vary from 

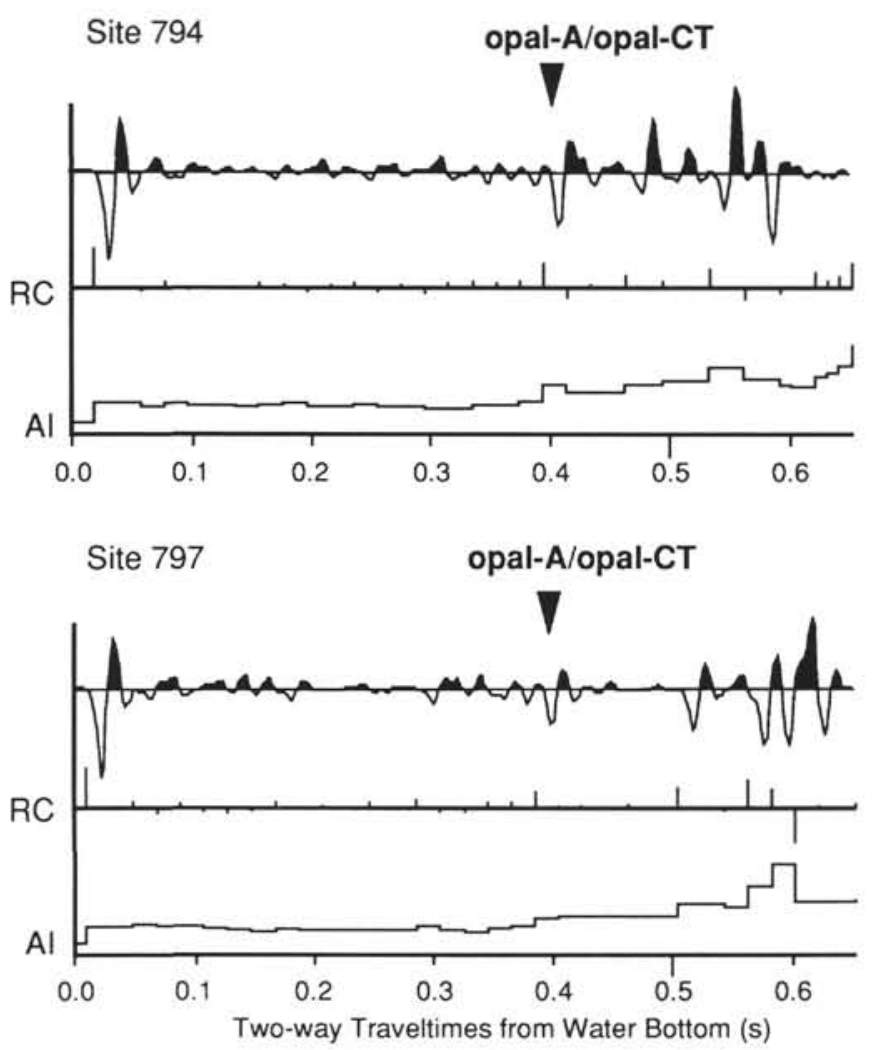

Figure 3. Synthetic seismogram calculated using density and velocity data obtained by shipboard physical property and downhole measurements for Sites 794 and 797. AI is acoustic impedance, RC is reflection coefficient. Horizontal axes show two-way traveltime below water bottom in seconds. The opal-A/opal-CT reflector is easily seen in both seismograms. Arrow shows location of BSR identified from seismic reflection profiles.

20 to $50 \mathrm{~m} / \mathrm{m} . \mathrm{y}$. For example, for a sedimentation rate increase of $10 \mathrm{~m} / \mathrm{m} . \mathrm{y}$. at $0.4 \mathrm{~s}$ two-way traveltime (TWT) of the BSR, the surface heat flow value will increases about 10 to $15 \mathrm{~mW} / \mathrm{m}^{2}$ (Fig. 8B). The variability of BSR-derived heat flow estimates is lower than the error value for probe heat flow measurements, which have an estimated $20 \%$ error. The ODP drilling results show fairly good coincidence about the sedimentation rates in the Yamato Basin, Sites 794 and 797. The cored sediments do not show evidence of turbidite sedimentation in the sections above the opal-A/opal-CT boundary. The sedimentation rate, even in the middle of the Yamato Basin, should be the same as the drilling results. We therefore use the sedimentation rate based on the drilling results to estimate the surface heat flow values throughout the Yamato Basin.

\section{BSR-Derived Heat Flow vs. Probe Heat Flow}

The Yamato Basin heat flow values show only a small amount of variation, $\left(\right.$ standard deviation $=21.7 \mathrm{~mW} / \mathrm{m}^{2}$ ), except for a value of $223 \mathrm{~mW} / \mathrm{m}^{2}$ in the southeastern part of the basin (Fig. 5). The mean value is $94 \mathrm{~mW} / \mathrm{m}^{2}$ within the shaded area in Figure 5. Tamaki (1985) estimated that the average value of heat flow for the Yamato Basin at about $98 \mathrm{~mW} / \mathrm{m}^{2}$ after some editing of the data. These previous studies suggest that the Yamato Basin has a uniform heat flow throughout the basin.

Yamano et al. (1987) made several heat flow measurements on the multichannel seismic profile (Line DELP-B) in the southern part of the Yamato Basin (Fig. 1). This multichannel line shows the best reflection image of the BSR in the Yamato Basin. This profile thus provides an opportunity to compare both types of data. Figure 9 shows a comparison between the calculated BSR heat flow values and the measured probe data in the Yamato Basin. The opal-A/opal-CT BSR can be easily identified as a normal polarity, strong reflector and is observed at about $0.5 \mathrm{~s}$ TWT below seafloor throughout the profile. The BSR depths are converted into heat flow values using the relationship between BSR depth and heat flow value with a constant sedimentation rate (Fig. 7). The estimated BSR heat flow values are in fairly good agreement with the heat flow probe data except at one point, which may reflect a high sedimentation rate in that area. One of the great advantages of using BSR-derived heat flow values is that the estimation produces continuous data along seismic profiles. This comparison supports the validity of using the opal-A/opal-CT BSR for the estimation of the surface heat flow values.

\section{DISCUSSION}

The fundamental problem of the formation of the Japan Sea has only been partly elucidated by onland geological or geophysical studies (see Tamaki, 1988). The thermal structure of the Yamato Basin is important for understanding its formation, because there were no significant thermal events after the formation of the basin based on interpretation of seismic reflection profiles (Tokuyama et al., 1987). This study attempts to provide some constraints to the estimation of thermal regime of the Yamato Basin.

We apply the BSR age-temperature relationship to estimate the heat flow values with a constant sedimentation rate to two areas that include the ODP sites, Sites 794 and 797 . We used single-channel seismic profiles collected by the Geological Survey of Japan (Honza, 1978a, 1978b, 1979) and multichannel profiles collected by the Ocean Research Institute, University of Tokyo (Tokuyama et al., 1987; unpubl. data). Figures 1 and 10 show the location of data points in the two areas where good seismic coverage is available.

In area $\mathrm{A}$, there are 134 data points taken from available seismic profiles. Toyama Deepsea Fan deposits cover the western half of this area. According to the results of DSDP Leg 31 (Karig, Ingle et al., 1975), the base of upper transparent section in the seismic profiles is at about $2 \mathrm{Ma}$ in age, which can be interpreted as the base of the fan deposits. We adopt this for the age of the base of upper horizon, transparent section, in the seismic profiles. The sedimentation rate based on the ODP drilling results was then used for the lower section to estimate the age of host rock of the BSR. Figure 11 shows the BSR host rock ages for area A. Then the age data are converted into heat flow data (Fig. 12) based on the relationship between the depth of the opal-A/opal-CT BSRs and the surface heat flow values (Fig. 7). We also plotted some probe heat flow data on that figure. The comparison between the BSR heat flow and the probe heat flow shows 20\%-30\% discrepancy (Fig. 12). The BSR heat flow estimation shows higher values than the probe heat flow values. The BSR-derived heat flow also shows a significant heat flow anomaly in the southern and northeastern parts of that area. The difference may reflect the incorrect assumption of constant sedimentation rate as a primary effect. Two possible reasons for the error may be pointed out. One is that the present BSR may be a relict BSR. Deposition of the Toyama Deepsea Fan may have eroded the sediments above the opal-A/opal-CT BSR. In this case, the opal-A/opal-CT BSR will appear younger than its true age and the BSR heat flow values would be too high. The other possibility is that the Toyama Deepsea Channel may cause a lateral flux of fluid along a permeable horizon. In the upper section of the Toyama Deepsea Fan deposits there may be permeable sediments. If there is lateral fluid migration, the probe heat flow values will underestimate the true values. We cannot rule out the possibility of heat flow anomaly in this area, but we cannot confirm the BSR heat flow values by the existing probe data.

In area $\mathrm{B}$, there are 115 data points taken from available seismic profiles (Fig. 10). There are no significant Toyama Deepsea Fan deposits in this area. The host rock ages are estimated from the BSR depth (Fig. 13), and the distribution of BSR heat flow values is 


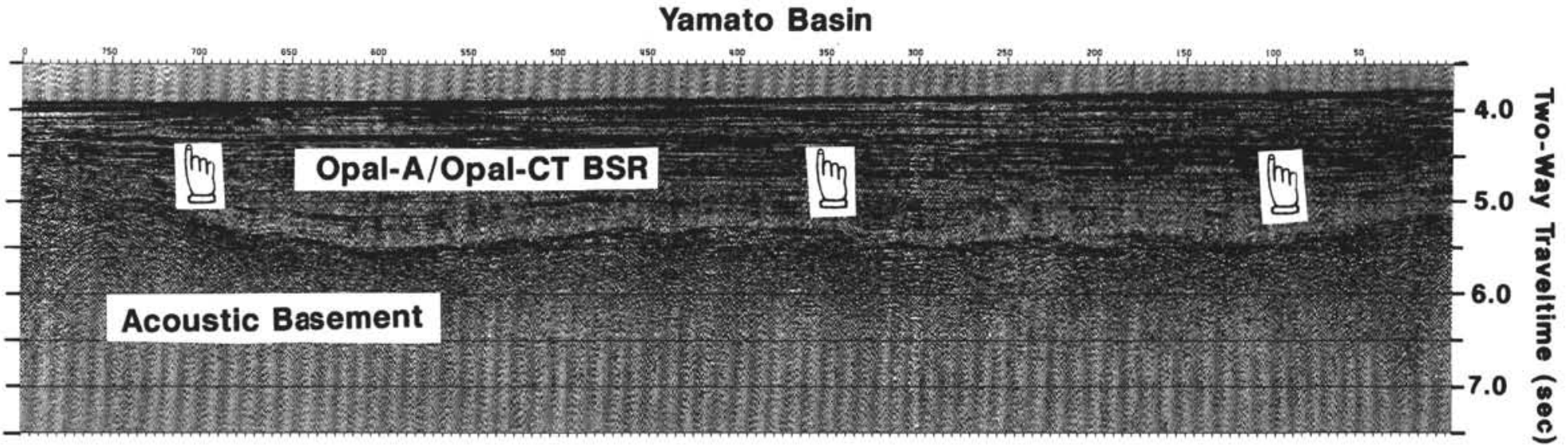

Figure 4. Example of the opal-A/opal-CT BSR in the Yamato Basin. The opal-A/opal-CT BSR appears as a strong reflector at about $4.5 \mathrm{~s}$ TWT. This reflector is almost parallel to other sedimentary reflectors, but it is recognized as a high-amplitude, normal polarity reflector (arrows). Location of seismic profile is shown in Figure 1 . 


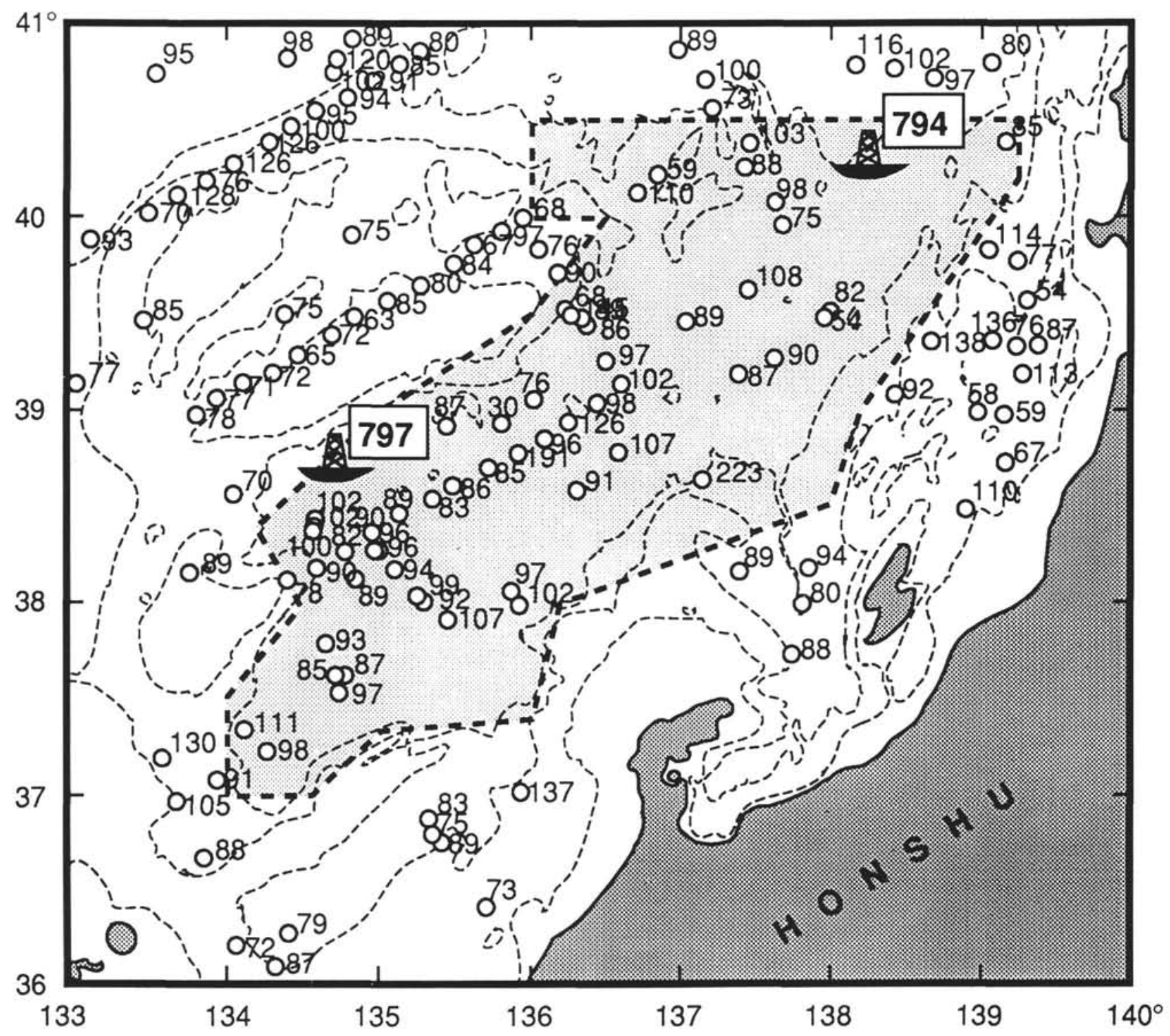

Figure 5. The distribution of heat flow probe data in the Yamato Basin (Yasui et al., 1966; Yamano et al., 1987). The average value is $94 \mathrm{~mW} / \mathrm{m}^{2}$ within the shaded area.

shown in Figure 14. Most probe heat flow values are less than $100 \mathrm{~mW} / \mathrm{m}^{2}$. The BSR heat flow values show much variability in this area. A low heat flow area is observed in the northwestern quadrant and a high heat flow anomaly is seen in the northeast. There are no probe data in the high heat flow region, but some high heat flow values are detected by probe in the southwestward continuation of the high heat flow anomaly area (Fig. 5). Thus, we suggest that there is a possibility of heat flow anomaly in the Yamato Basin. In area B, there is little difference between the probe heat flow and the opal-A/opal-CT BSR heat flow (less than 20\%). The BSR heat flow identified the heat flow anomaly in northeastern part of this area, where we lacked probe data. It may be a significant and convenient method to estimate heat flow over a wide area by the opal-A/opal-CT BSR.

\section{CONCLUSIONS}

We have evaluated the use of the opal-A/opal-CT phase change boundary for the estimation of the surface heat flow values using seismic profiles in the Yamato Basin. First, we determined the rela- tionship between the host rock age and the temperature at the silica phase transition boundary (opal-A to opal-CT) at ODP Legs 127 and 128 drill sites. An abrupt density change, due to the silica phase change, creates a BSR that can be clearly seen in seismic reflection profiles. The host rock ages of the BSR were estimated assuming constant sedimentation rates in the Yamato Basin. The estimated BSR heat flow values showed good agreement with individual probe heat flow data in the southern part of the Yamato Basin. This was confirmed on the multichannel seismic profile. We estimated surface heat flow values around ODP drilling sites, and they appear to be valid. However, precise estimation of heat flow values needs high-quality seismic profiles and confirmed stratigraphic data.

In conclusion, the opal-A/opal-CT BSR is useful for estimating the general trend of heat flow in the basin. The current method has a significant capability for detecting heat flow values continuously and regionally along ship tracks. This method can be used to great advantage to estimate the thermal structure of the Yamato Basin and other basins that have siliceous deposits. 


\section{ACKNOWLEDGMENTS}

We thank S. Uyeda of Tokai University and an anonymous reviewer for their critical reviews. We thank M. Yamano, Earthquake Research Institute, University of Tokyo, for his thoughtful review of our paper. S. Kuramoto thanks A. Klaus of Ocean Research Institute, University of Tokyo, for his helpful review. This work was partially supported by grants from the Japanese Ministry of Education, Science and Culture, for research (No. 01790340).

\section{REFERENCES}

Aoki, Y., Tamano, T., and Kato, S., 1982. Detailed structure of the Nankai Trough from migrated seismic sections. In Watkins, J. S., and Drake, C. L. (Eds.), Studies in Continental Margin Geology: AAPG Mem., 34:309-322.

Bryan, G. M., 1974. In situ indication of gas hydrate. In Kaplan, I. R. (Ed.), Natural Gases in Marine Sediments: New York (Plenum), 299-308.

Grechin, V. I., Pisciotto, K. A., Mahoney, J. J., and Gordeeva, S. N., 1981. Neogene siliceous rocks and sediments off southern California and Baja California. In Yeats, R. S., Haq, B. U., et al., Init. Repts. DSDP, 63: Washington (U.S. Govt. Printing Office), 579-593.

Hein, J. R., Scholl, D. W., Barron, J. A., Jones, M. G., and Miller, J., 1978. Diagenesis of late Cenozoic diatomaceous deposits and formation of the bottom simulating reflector in the southern Bering Sea. Sedimentology, 25:155-181.

Honza, E. (Ed.), 1978a. Geological investigation in the northern margin of the Okinawa Trough and the western margin of the Japan Sea. Geol. Surv. Jpn. Cruise Rept., 10.

1978b. Geological investigation of the Okhotsk and Japan Seas off Hokkaido. Geol. Surv. Jpn. Cruise Rept., 11.

, 1979. Geological investigation of the Japan Sea. Geol. Surv. Jpn. Cruise Rept., 13.

Hubbard, R. J., Pape, J., and Roberts, D. J., 1985. Depositional sequence mapping as a technique to establish tectonic and stratigraphic framework and evaluate hydrocarbon potential on a passive continental margin. In Berg, O. R., and Woolverton, D. G. (Eds.), Seismic Stratigraphy II: An Integrated Approach to Hydrocarbon Exploration. AAPG Mem., 39:79-91.

Hurd, D. C., 1972. Factors affecting solution rate of biogenic opal in seawater. Earth Planet. Sci. Lett., 15:411-417.

Iijima, A., and Tada, R., 1981. Silica diagenesis of Neogene diatomaceous and volcaniclastic sediments in northern Japan. Sedimentology, 28:185-200.

Ingle, J. C., Jr., Suyehiro, K., von Breymann, M. T., et al., 1990. Proc. ODP, Init. Repts., 128: College Station, TX (Ocean Drilling Program).

Jones, J. B., and Segnit, E. R., 1971. The nature of opal I. Nomenclature and constituent phases. J. Geol. Soc. Aust., 18:57-68.

Karig, D. E., Ingle, J. C., Jr., et al., 1975. Init. Repts. DSDP, 31: Washington (U.S. Govt. Printing Office).

Kastner, M., Keene, J. B., and Gieskes, J. M., 1977. Diagenesis of siliceous oozes I. Chemical controls on the rate of opal-A to opal-CT transformation-an experimental study. Geochim. Cosmochim. Acta, 41:1041-1059.

Lancelot, Y., 1973. Chert and silica diagenesis in sediments from the Central Pacific. In Winterer, E. L., Ewing, J. I., et al., Init. Repts. DSDP, 17: Washington (U.S. Govt. Printing Office), 377-405.
Lewin, J. C., 1961. The dissolution of silica from diatom walls. Geochim. Cosmochim. Acta, 21:182-198.

Mizutani, S., 1966. Transformation of silica under hydrothermal conditions. Nagoya Univ. J. Earth Sci., 14:56-88.

, 1970. Silica minerals in the early stage of diagenesis. Sedimentology, 15:419-436.

Murata, K. J., and Nakata, J. K., 1974. Cristobalitic stage in the diagenesis of diatomaceous shale. Science, 184:567-568.

Pisciotto, K. A., 1981. Distribution, thermal histories, isotopic compositions, and reflection characteristics of siliceous rocks recovered by the Deep Sea Drilling Project: a decade of progress. Spec. Publ.-Soc. Econ. Paleontol. Mineral., 32:129-147.

Shipley, T. H., Houston, M. H., Buffler, R. T., Shaub, F. J., McMillen, K. J., Ladd, J. W., and Worzel, J. L., 1979. Seismic evidence for widespread possible gas hydrate horizons on continental slopes and rises. AAPG Bull., 63:2204-2213.

Siever, R., 1962 . Silica solubility, $0 q^{\circ}-200^{\circ} \mathrm{C}$, and the diagenesis of siliceous sediments. J. Geol., 70:127-150.

Tada, R., 1991. Compaction and cementation in siliceous rocks and their possible effect on bedding enhancement. In Einsel, G., Ricken, W., and Seilacher, A. (Eds.), Cycles and Events in Stratigraphy: New York (Springer).

Tamaki, K., 1985. Age of the Japan Sea. Chigaku Zasshi, 94:14-29.

, 1988. Geological structure of the Japan Sea and its tectonic implications. Chishitsu Chosasho Geppo, 39:269-365.

Tamaki, K., Pisciotto, K., Allan, J., et al., 1990. Proc. ODP, Init. Repts., 127: College Station, TX (Ocean Drilling Program).

Tokuyama, H., Suyemasu, M., Tamaki, K., Nishiyama, E., Kuramoto, S., Suyehiro, K., Kinoshita, H., and Taira, A., 1987. Report on DELP 1985 cruises in the Japan Sea part III: seismic reflection studies in the Yamato Basin and the Yamato Rise area. Tokyo Daigaku Jishin Kenkyusho Iho, 62:367-390.

White, J. F., and Corwin, J. F., 1961. Synthesis and origin of chalcedony. Am. Mineral., 46:112-119.

Wollast, R., 1974. The silica problem. In Goldberg, E. D. (Ed.), The Sea (Vol. 5): New York (Wiley), 359-392.

Yamano, M., Uyeda, S., Uyeshima, M., Kinoshita, M., Nagihara, S., Boh, R., and Fujisawa, H., 1987. Report on DELP 1985 cruises in the Japan Sea part V: heat flow measurements. Tokyo Daigaku Jishin Kenkyusho Iho, 62:417-432.

Yasui, M., Kishii, T., Watanabe, T., and Uyeda, S., 1966. Studies of the thermal state of the earth. The 18th paper: terrestrial heat flow in the Japan Sea (2). Tokyo Daigaku Jishin Kenkyusho Iho, 44:1501-1518.

Yoshii, T., 1972. Terrestrial heat flow and features of the upper mantle beneath the Pacific and Sea of Japan. J. Phys. Earth, 20:271-285.

Date of initial receipt: 19 March 1991

Date of acceptance: 5 February 1992

Ms 127/128B-235 


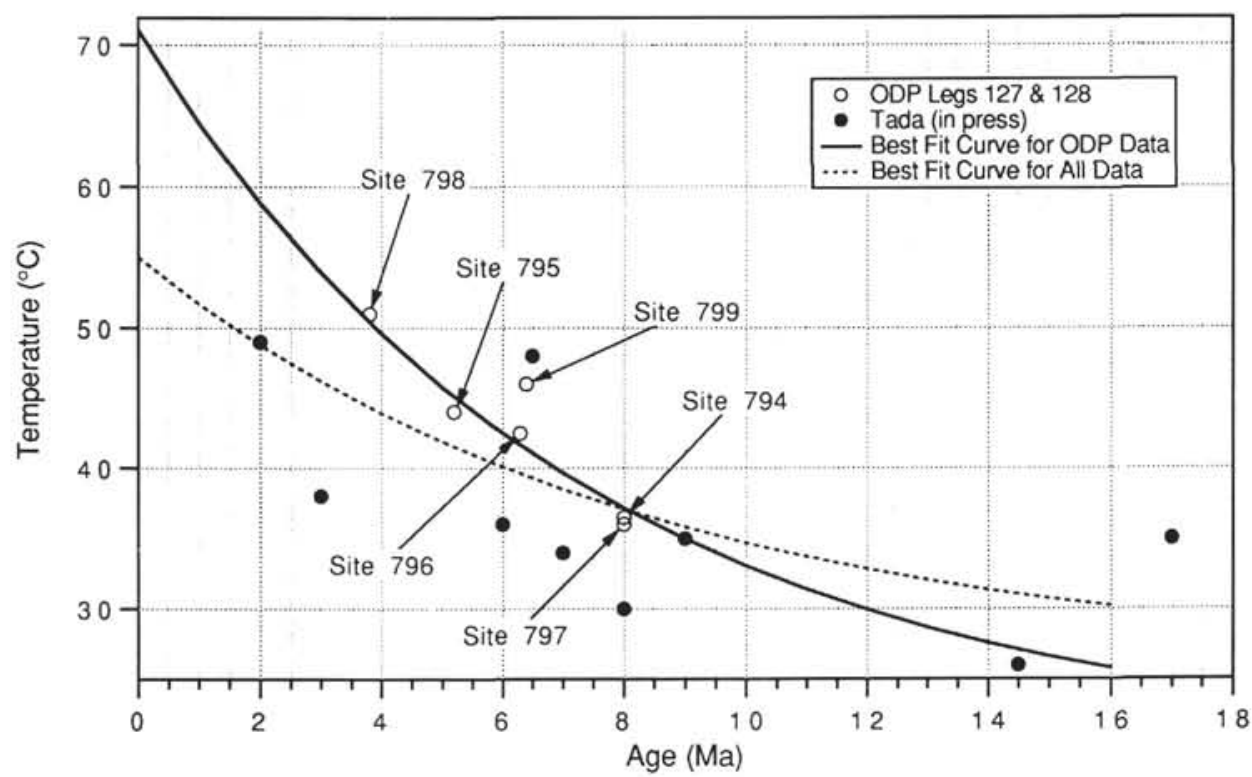

Figure 6. Opal-A/opal-CT transition temperature plotted vs. age of the host rocks at drill sites in the Yamato Basin. Open circles show ODP Leg 127 and 128 results. Solid circles show data from DSDP and test wells of northern Japan (Tada, 1991). Solid line shows a best fit curve for the open circles, dashed line shows a best fit curve for all the data.

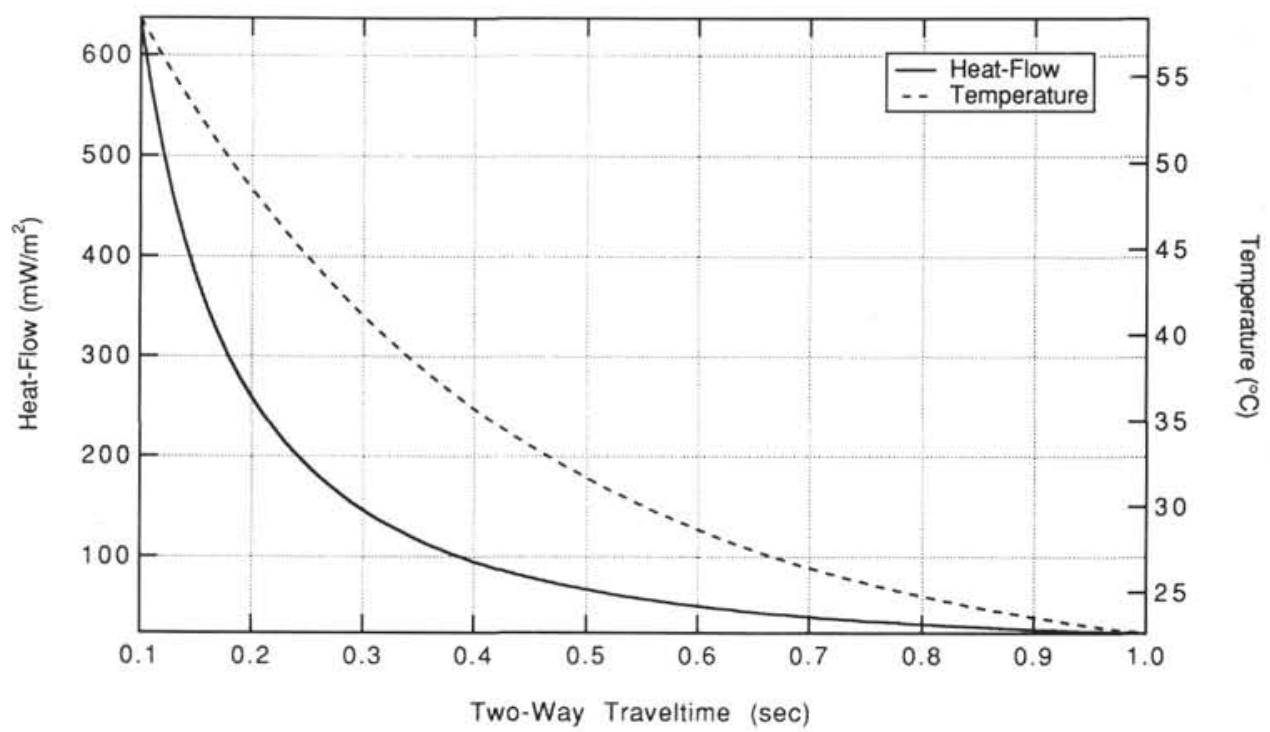

Figure 7. Surface heat flow and temperature vs. two-way traveltime of the opal-A/opal-CT BSR assuming a constant sedimentation rate of $37 \mathrm{~m} / \mathrm{m} . \mathrm{y}$. Solid line shows heat flow, dashed line shows temperature. 


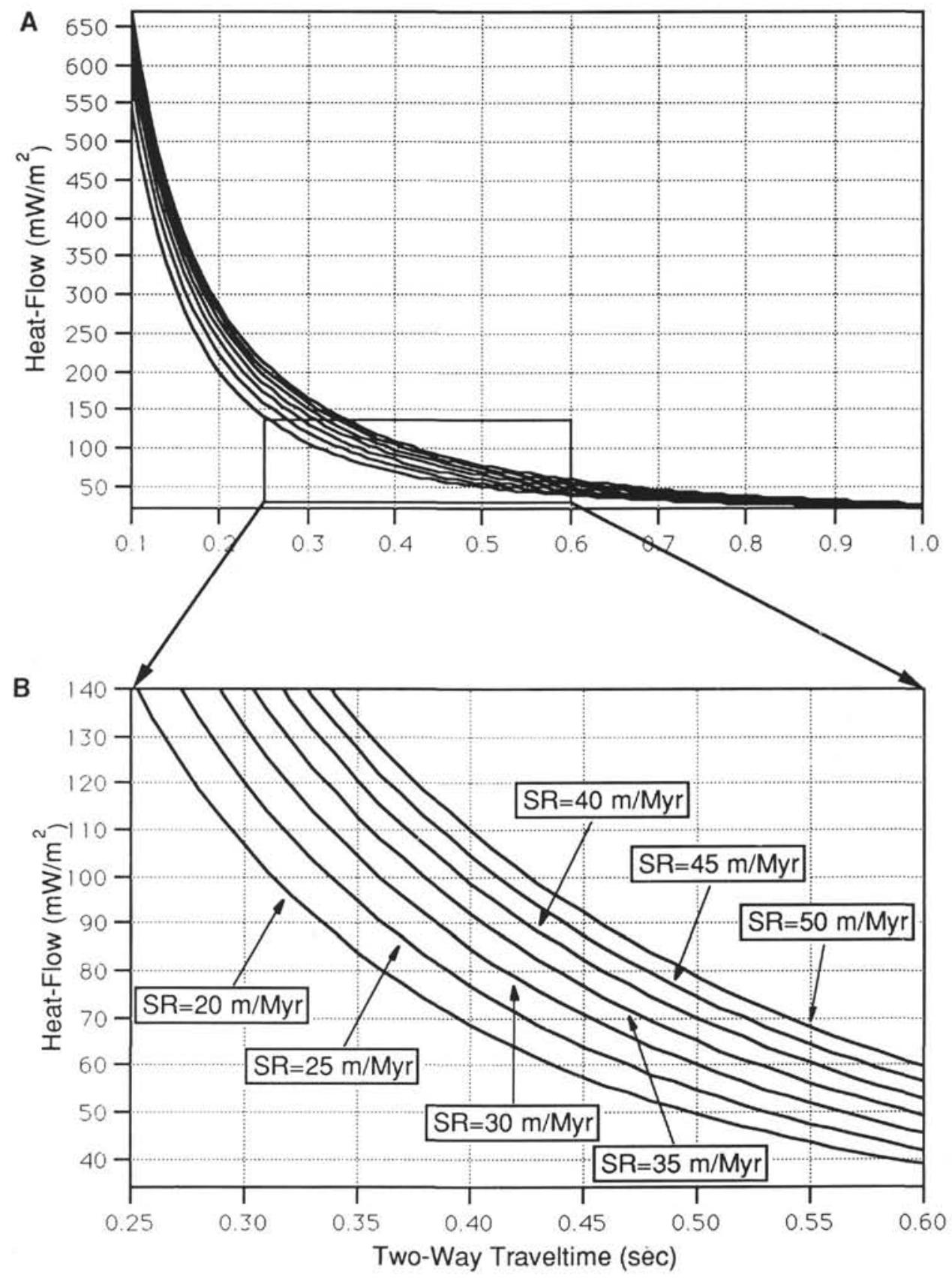

Figure 8. A. Relationship between the two-way traveltime of opal-A/opal-CT BSR and the estimated heat flow values at various sedimentation rates. B. Close-up of Figure 8A between 0.25 and $0.60 \mathrm{~s}$ TWT. 


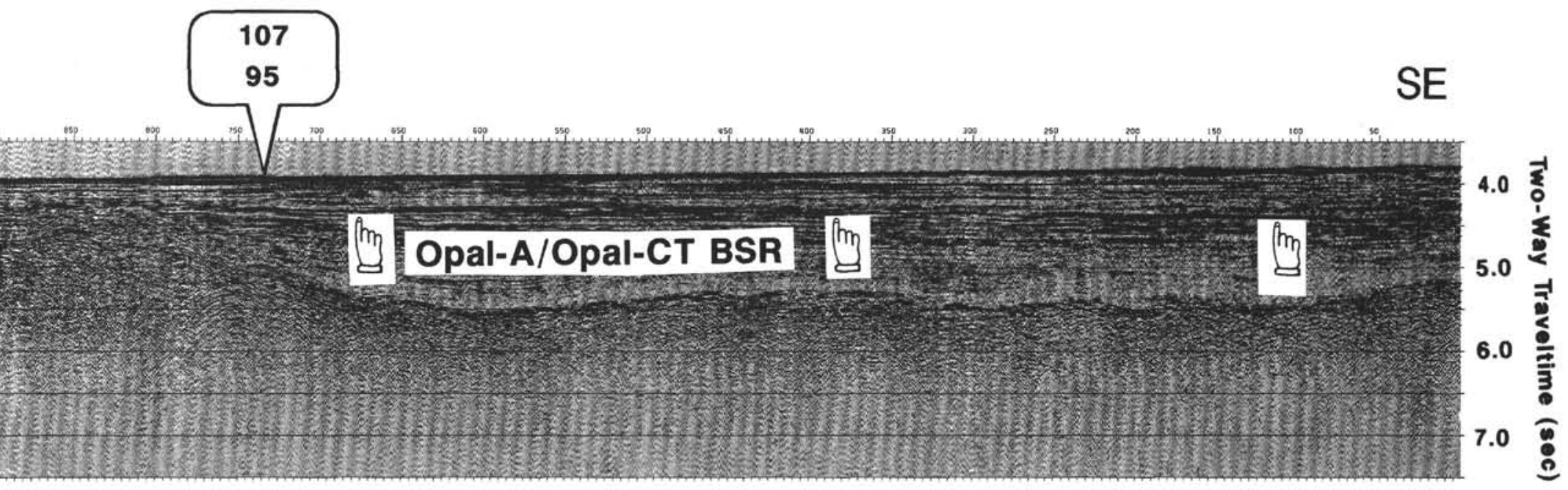
$\mathbf{N}$

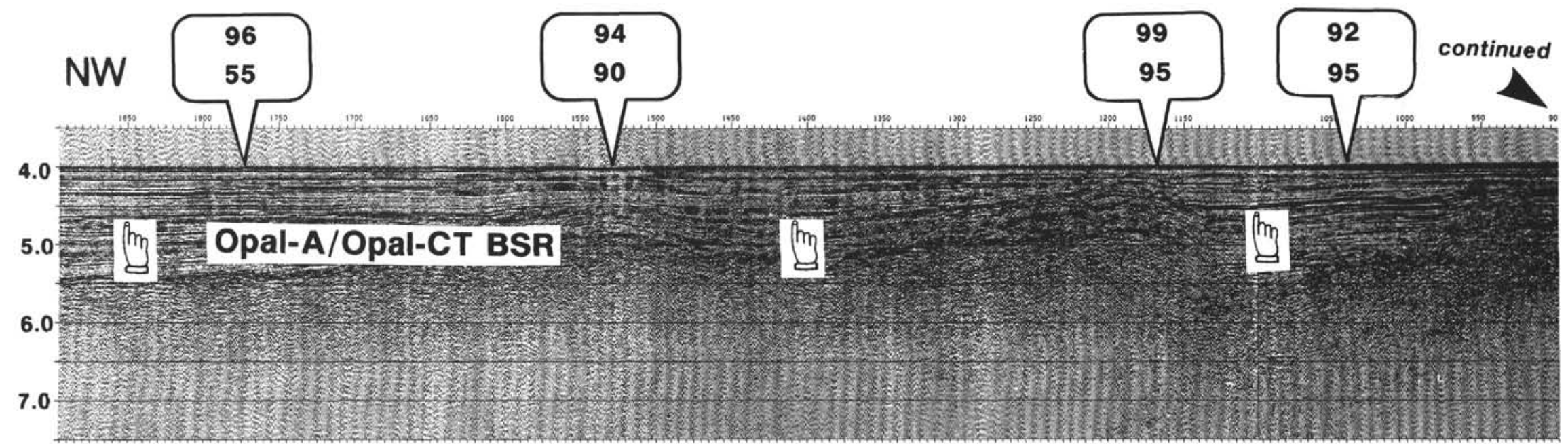

Figure 9. Comparison between the probe heat flow and the BSR-derived heat flow values on multichannel seismic profile (Line DELP-B). Upper values show the probe heat flow values (Yamano et al., 1987) and lower values show the BSR-derived heat flow values at each point. The opal-A/opal-CT BSR is indicated by arrow. Location of seismic profile is shown in Figure 1. 


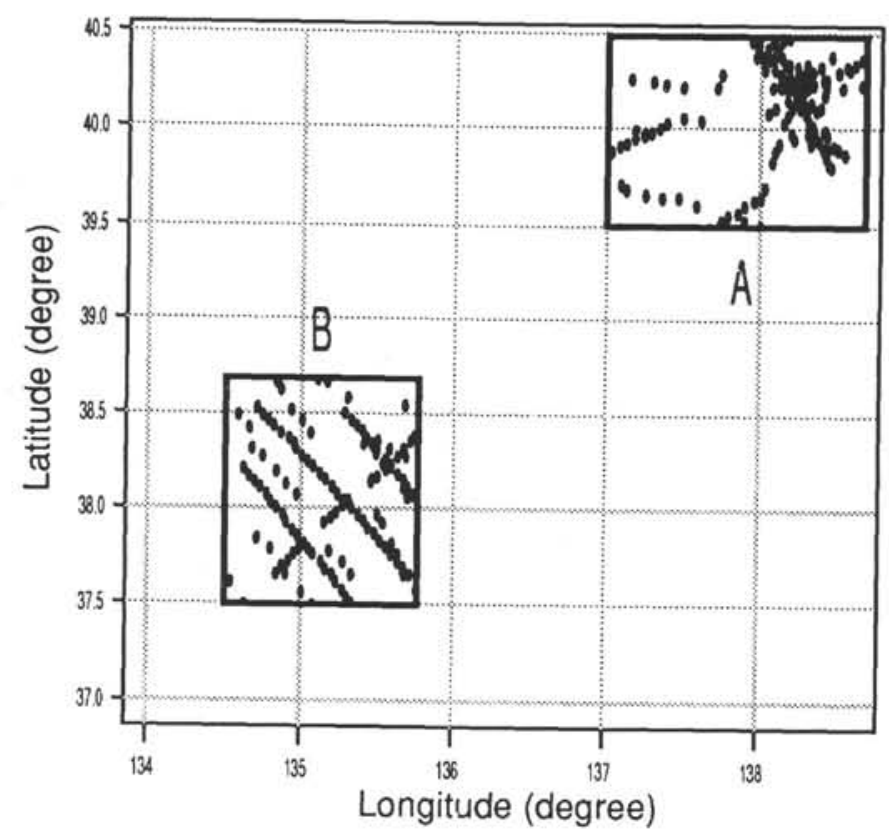

Figure 10. BSR data points picked from seismic profiles for areas A and B in the Yamato Basin. Locations of these two areas are shaded in Figure 1.

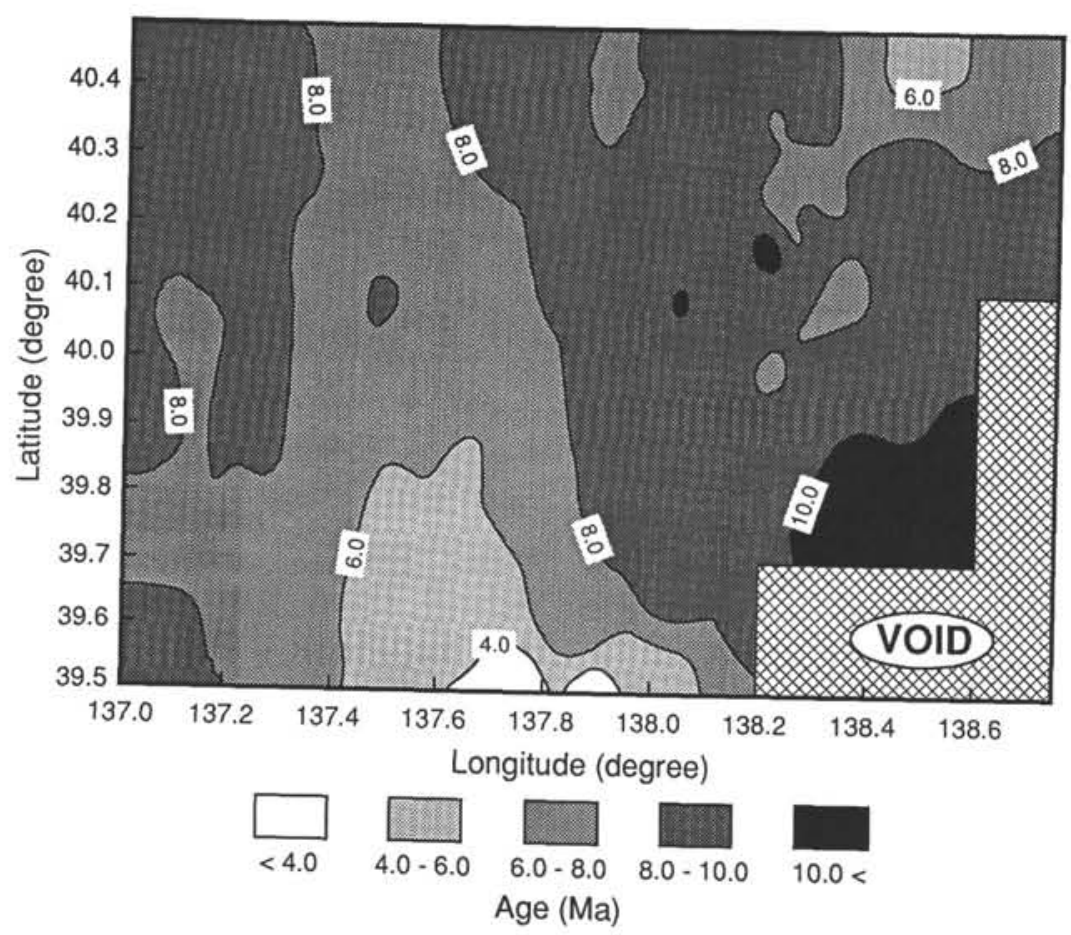

Figure 11. Contour map of the estimated ages of BSR host rocks in the northern part of the Yamato Basin (area A). See Figures 1 and 10 for location. 


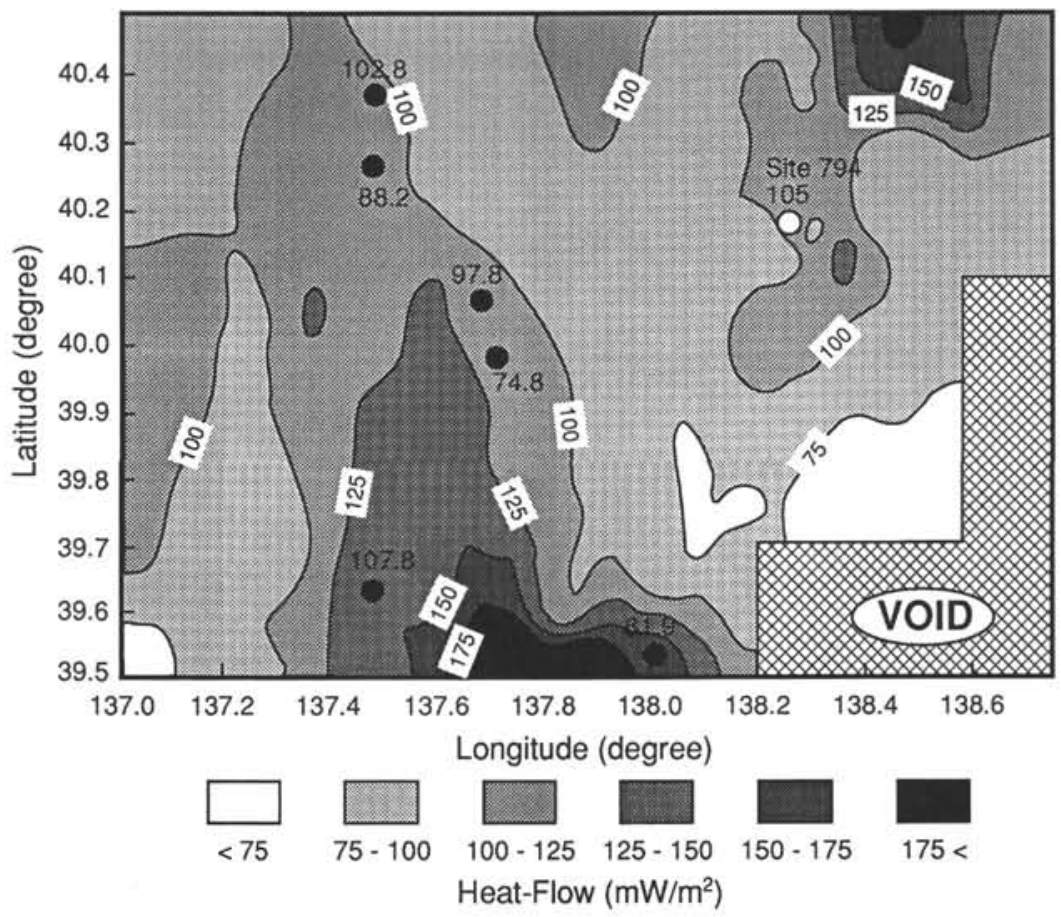

Figure 12. Contoured surface heat flow values estimated from BSR data ( $\operatorname{area} \mathrm{A})$. Solid circles show probe heat flow data collected by previous studies. Open circle shows the location of Site 794 and its heat flow value (see Langseth and Tamaki, this volume). See Figures 1 and 10 for location.

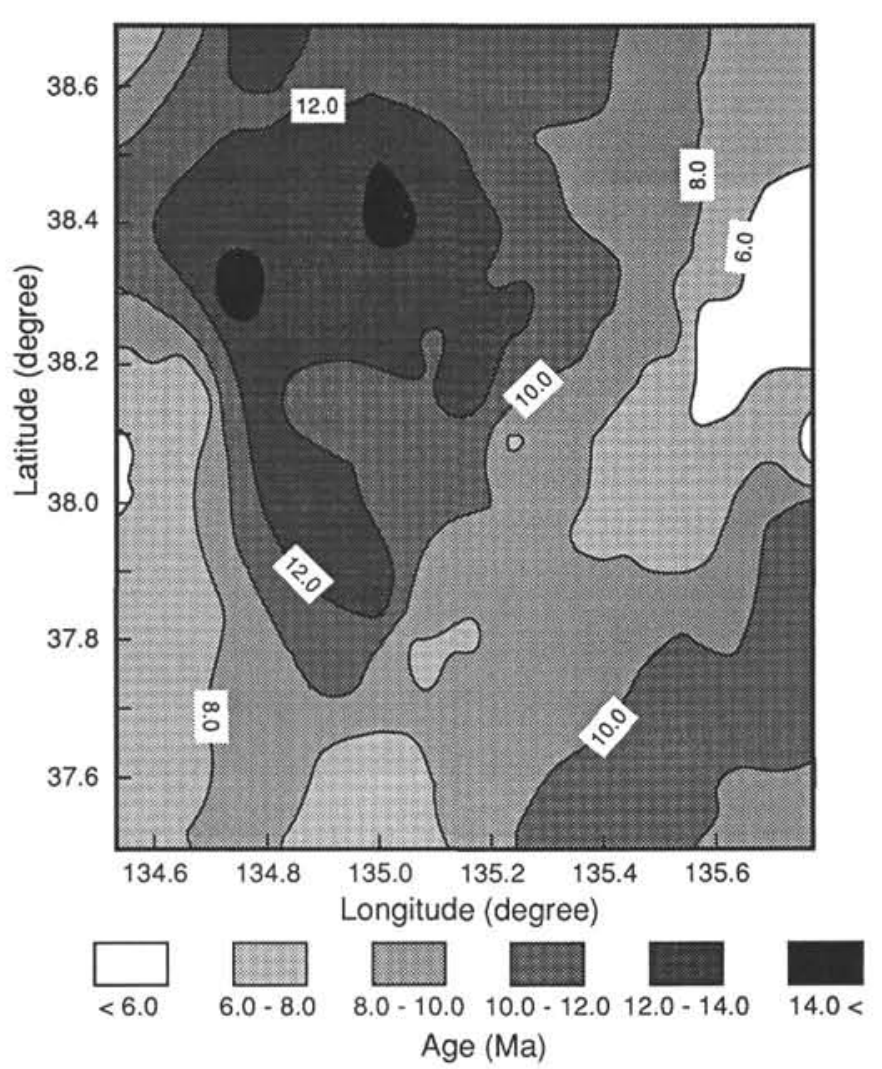

Figure 13. Contour map of the estimated ages of BSR host rocks in the southern part of the Yamato Basin (area B). See Figures 1 and 10 for location.

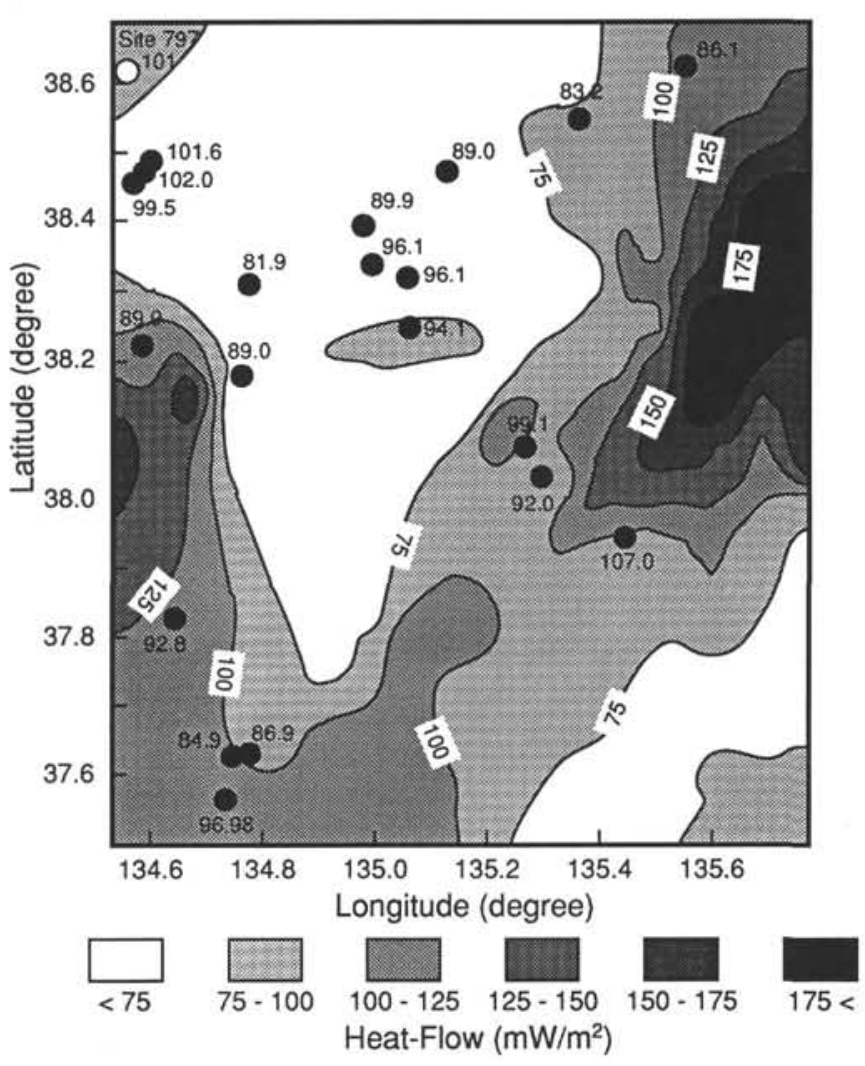

Figure 14. Contoured surface heat flow values estimated from BSR (area B). Solid circles show probe heat flow data collected by previous studies. Open circle shows the location of Site 797 and its heat flow value (see Langseth and Tamaki, this volume). See Figures 1 and 10 for location. 